\title{
Climate change is a major stressor causing poor pregnancy outcomes and child development [version 1; peer review: 3
}

\section{approved]}

\author{
David M. Olson'1, Gerlinde A.S. Metz² \\ ${ }^{1}$ Department of Obstetrics and Gynecology, University of Alberta, 220 HMRC, Edmonton, Alberta, T6G 2S2, Canada \\ ${ }^{2}$ Canadian Centre for Behavioural Neuroscience, Department of Neuroscience, University of Lethbridge, Lethbridge, Alberta, T1 $\mathrm{K}$ \\ $3 \mathrm{M} 4$, Canada
}

V1 First published: 09 Oct 2020, 9(Faculty Rev):1222
https://doi.org/10.12688/f1000research.27157.1

Latest published: 09 Oct 2020, 9(Faculty Rev):1222

https://doi.org/10.12688/f1000research.27157.1

\section{Open Peer Review}

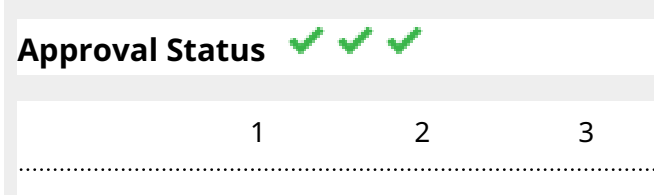

version 1

09 Oct 2020

Faculty Reviews are review articles written by the prestigious Members of Faculty Opinions. The articles are commissioned and peer reviewed before publication to ensure that the final, published version is comprehensive and accessible. The reviewers who approved the final version are listed with their names and affiliations.

1. Katie Hayes, Climate Change and Innovation Bureau, Health, Toronto, Canada

2. Lindsay Galway, Lakehead University,

Thunder Bay, Canada

3. Kevin Chan, University of Toronto, Toronto, Canada

Any comments on the article can be found at the end of the article. 


\section{Keywords}

Climate change, mental health, mothers, fathers, pregnancy, adverse

outcomes, children, developmental trajectories

Corresponding author: David M. Olson (dmolson@ualberta.ca)

Author roles: Olson DM: Conceptualization, Formal Analysis, Funding Acquisition, Project Administration, Supervision, Writing - Original Draft Preparation, Writing - Review \& Editing; Metz GAS: Conceptualization, Formal Analysis, Funding Acquisition, Project

Administration, Supervision, Writing - Original Draft Preparation, Writing - Review \& Editing

Competing interests: No competing interests were disclosed.

Grant information: This work was supported by grants from the Worldwide Universities Network (DMO) and the Canadian Institutes of Health Research IL-1 grant:168858 (DMO \& GASM).

The funders had no role in study design, data collection and analysis, decision to publish, or preparation of the manuscript.

Copyright: ( 2020 Olson DM and Metz GAS. This is an open access article distributed under the terms of the Creative Commons

Attribution License, which permits unrestricted use, distribution, and reproduction in any medium, provided the original work is properly cited.

How to cite this article: Olson DM and Metz GAS. Climate change is a major stressor causing poor pregnancy outcomes and child development [version 1; peer review: 3 approved] F1000Research 2020, 9(Faculty Rev):1222

https://doi.org/10.12688/f1000research.27157.1

First published: 09 Oct 2020, 9(Faculty Rev):1222 https://doi.org/10.12688/f1000research.27157.1 


\section{Introduction}

The earth is warming because of the effects of greenhouse gas emissions, and this warming trend is accelerating and will continue for many years until better controls are put into place, targets are met, and alternative energy sources are commonplace. Even if all nations were to meet the commitments of the 2015 Paris Accord, the global temperature will continue to rise by $1.5{ }^{\circ} \mathrm{C}$ by $2100^{1}$. Irrefutable evidence exists that for some time to come there will be an increased number of catastrophic consequences due to the existing climate crisis. There will be more extreme weather conditions (e.g. hurricanes and typhoons), increased air and land pollution, increased ultraviolet radiation, ocean acidification, and rising sea levels. These will lead to more heatwaves, drought, and wildfires, reduced crop yields, food insecurities (reduced agricultural capacity, livestock, and aquaculture productivity), and floods, which along seacoasts will lead to more migration from cities under water. The consequential loss of biodiversity and ecosystem collapse will cause an increased number of pests and vector-borne diseases and a host of adverse health outcomes. We will experience increased risk of non-communicable diseases (NCDs) including obesity, type II diabetes, and heart/cardiovascular issues, more respiratory disease including asthma and pollen allergenicity burden, and more harmful algal blooms. Already it is evident that NCDs increase an individual's risk for communicable disease (e.g. COVID-19) and vice versa. These problems will be exacerbated by the concomitant climate crisis calamities of loss of human habitation, poverty, mass migrations, and violent conflicts. The richest nations are contributing the most to the crisis, but the poorest nations are bearing the brunt of the consequences. These environmental, social, and health risks will consolidate on worsening mental health and increased morbidity and mortality of humankind and consequent loss of capacity to deal with the crisis ${ }^{1,2}$.

The climate crisis is the existential threat of our times and for generations to come. These are no longer threats but realities affecting us, our children, and the generations that follow. At the apex of the health impact pyramid are pregnant mothers, their fetuses, and their children because they are among the most atrisk individuals in every population and every jurisdiction ${ }^{3-5}$. Importantly, the health of Indigenous mothers and their children is a particularly critical issue since Indigenous Peoples' communities are the most directly threatened by climate change ${ }^{5,6}$. This review will explore the topic of prenatal maternal stress (PNMS) and paternal stress, allostatic load, and the effect of degradation of the environment on individuals. These will be examined in relation to adverse pregnancy outcomes and altered developmental trajectories of children. This exploration will reveal a public health paradox whereby many of the global gains made in recent decades in maternalchild health will be nullified by the losses due to climate change ${ }^{7}$.

\section{Pregnant women and their developing children are one of the groups most at risk of the effects of the climate crisis}

The application of intersectionality theory to assess the relative risk of various populations to health inequities due to climate change is an emerging practice ${ }^{8,9}$. Diverse subgroups emerge as having greater risk, which include pregnant mothers and their young children along with the elderly ${ }^{7}$. Critically, though, newborns who are victims of climate change, either directly or indirectly by being the conceptuses/fetuses of women and men affected by climate change, may have an entire lifetime of chronic disease or lost capacity ahead of them. Increasing temperatures and heat exposure and the associated physical stresses increase delivery risk for pregnant women, especially shorter gestations ${ }^{10}$. In a systematic review where "environmental temperature" and "climate change" were associated with various adverse pregnancy outcomes, all studies that fit the study criteria reported a significant relationship between climate change-related exposures and several adverse pregnancy outcomes: eclampsia, preeclampsia, cataract, low birth weight, preterm birth, hypertension, sex ratio, and length ${ }^{11}$. The estimation is that 25,000 infants per year between 1969 and 1988 were born earlier than normal (39-40 weeks' gestation) as a result of heat exposure, with a total loss of 150,000 gestational days per year $^{10}$. Without intervention, the estimate is that by the end of the century there will be an additional loss of 250,000 days of gestation per year ${ }^{10}$. The World Health Organization estimates that $88 \%$ of the burden of disease attributable to climate change occurs in children younger than 5 years ${ }^{12}$. Climate change puts children at risk of post-traumatic stress disorder (PTSD), depression, anxiety, phobias, sleep disorders, attachment disorders, and substance abuse, which in turn make them vulnerable to problems with emotional regulation, cognition, learning, behavior, language development, and academic performance ${ }^{12}$. In addition, these early life experiences have a long-lasting impact on the developmental trajectories also known as "life-course effects"13,14. For example, when exposed to heat during the prenatal and early life period, adolescents show lower academic attainment and fewer years of schooling ${ }^{15}$. Moreover, children exhibit high levels of concern over climate change, and these effects and concerns also lead to adverse adult mental health outcomes $^{16}$. The longer-term effect of PNMS and early childhood stress is the precocious development of NCDs. They account for $71 \%$ of deaths in the world and $75 \%$ of premature deaths in low- and middle-income countries (LMICs) ${ }^{17}$.

\section{Effects of the climate crisis on mental health}

In the 2016 Lancet report on sustainable development and global mental health, mental health is identified as the "most neglected of all human health conditions" and a "failure of humanity" $3,5,18$. Berry in 2010 pointed out that climate change may directly affect mental health through exposure of its victims to trauma and indirectly through primary effects on physical health and community wellbeing ${ }^{19}$. An excellent and exhaustive study of the relationship of current mental health knowledge and studies related to climate change and how healthcare systems can respond has been compiled by Hayes and her colleagues, ${ }^{5,20-22}$. In these reports, they emphasize that the amount of work relating climate change to mental health should be strengthened; for instance, at the community level, it remains understudied. In addition, it is just as important to understand the accumulation of stressful events prior to a natural disaster or other climate change-induced environmental event as it is to assess and mitigate the effects of the 
disaster after the event. On the contrary, not only may the effects of the event result in worse mental illness in some people but also, in different individuals, the event could promote the positive feelings of compassion and solidarity with others who experienced the same tragedy. A better understanding of these relationships is urgently required in order to reduce stress and promote individual and community resilience.

In spite of the work that has been done, the impact of climate change on youth mental health remains relatively unexplored ${ }^{23}$. Its effects on exacerbating poverty, malnutrition, and disease could serve as independent risk factors for the development of depression among youth, especially those living in developing nations where these are already serious problems. If youth are predisposed to depression and anxiety, then adding the mental health risks due to climate change to this existing burden could synergistically lead to dire outcomes. A unique challenge for youth is that their abilities to cope with these stresses and their levels of resilience are not yet fully developed, meaning that they have less of a buffer for mitigating the mental health risks of a climate disaster. As a consequence, they are more susceptible to climate change trauma and more likely to become depressed than older family members ${ }^{23-26}$. Left alone, these stresses may add to the overall allostatic load of youth maturing into adults and persisting into their preconception period of life.

A number of new concepts have emerged to better understand, study, and address the mental health impacts caused by climate and environmental change. Solastalgia, coined by Glenn Albrecht $^{27}$ (a conjunction of "solace" and "nostalgia"), is one of an emerging set of concepts collectively used for describing the effects of climatic and environmental change on mental health and wellness. This set of related emotional concepts has been described as "psychoterratic" or earth-related states ${ }^{28,29}$. Solastalgia is the distress caused by the transformation and degradation of one's home environment, including environmental degradation caused by climate change and associated natural disasters ${ }^{30}$. It can be applied equally to the mental health effects of environmental erosion of the ice pack on Inuit or to drought on western Australian farmers ${ }^{31}$. In just a few years, the concept has led to several academic reports and is already a field of investigation.

\section{Prenatal maternal stress leads to adverse} pregnancy, newborn, and generational outcomes Prenatal maternal stress and non-communicable diseases

The developmental origins of health and disease (DOHaD) approach $^{13}$ considers that multiple environmental factors operating on the mother before, during, and after pregnancy and breastfeeding can influence the development of the child in ways that may favor survival in the short term but may also compromise health in the longer term ${ }^{14}$. Increasing attention has been paid to the environment and experiences of the mother during pregnancy; consequently, PNMS has become an important subject of research. Reviews of the animal ${ }^{32-35}$ and human ${ }^{36-38}$ research on PNMS suggest that stressing the pre-conception or pregnant person or animal, or maternal exposure to depression or adverse life events in human pregnancy, including adverse childhood experience or chronic abuse $\mathrm{e}^{39,40}$, is associated with a host of negative pregnancy outcomes (e.g. preterm birth, preeclampsia, intrauterine growth retardation, or gestational diabetes mellitus) and adverse developmental trajectories for the newborn. These include especially neurodevelopmental and metabolic disorders such as childhood and adult $\mathrm{NCDs}^{41-44}$, neurodevelopmental impairments ${ }^{45}$ including anxiety disorder, conduct disorder, and attention-deficient hyperactive disorder, and even impaired adaptive immunity ${ }^{46}$. These have disastrous consequences for life-long health ${ }^{13,14}$.

Early life exposures impact health and disease risk in a sex-specific manner. Girls face greater psychosocial risks than boys ${ }^{47}$. While obesity risk is often greater in boys during childhood, women, later in life, are at a greater risk. Unhealthy behaviors and exposure to harmful environments in fathers affects generational transmission by sperm $^{48}$ and translates into increased NCD risk in offspring. These sex effects are nuanced by sociodemographic factors ${ }^{49}$ and often contribute to a disproportionately higher burden of NCDs upon women prior to, during, and after pregnancy. Sex often impacts the effectiveness of intervention ${ }^{50}$.

\section{PNMS and generational effects}

Collectively, the effects of stress appear to be particularly significant in preterm birth risk $^{51}$. Stress across and among generations can influence allostatic load as a prognostic factor. Factors affecting preterm birth risk can be inherited by the offspring from the maternal line ${ }^{52}$. Through permanently changing the inflammatory cytokine milieu, prenatal stress in the offspring can lead to pregnancy complications in later life ${ }^{53}$, be passed on to subsequent generations ${ }^{54}$, and influence adult disease $^{55,56}$ and behavior ${ }^{57-59}$. Thus, stress in the mother during pregnancy has the potential to shape physiological responses and adverse birth outcomes over multiple generations.

Studies using pregnant Long-Evans rats examined whether it was repetitive stress in each generation or a single stress to a previous generation that influenced pregnancy and developmental outcomes. They demonstrated that preterm birth risk and metabolic, endocrine, and behavioral consequences were "programmed" by inflicting gestational stress in the F0 parental generation (transgenerational stress) or by stressing each generation (multigenerational stress) ${ }^{60}$. Stressing every gestating generation led to numerous adverse pregnancy and newborn outcomes that accumulated with every subsequent generation. Interestingly, similar results were observed in the transgenerational model ${ }^{60}$. The implication of these observations is that PNMS caused by a climate change event can be passed on to succeeding generations through epigenetic means, even to the F3 generation. Therefore, the stress effects of a climate change event will likely last for several generations.

\section{PNMS and accumulation of stressors: allostatic load}

PNMS is characterized by a variety of stresses a pregnant mother can experience and that can impact her offspring's development and lifelong health. It is associated with a higher risk for neuropsychiatric diseases, such as anxiety and depression, 
and neurodevelopmental disorders as well as schizophrenia ${ }^{61-63}$. It is now widely acknowledged that maternal stress is both intergenerationally and transgenerationally passed on, probably via epigenetic mechanisms ${ }^{60,64-69}$. This transmission is believed to be independent of the stressor's timing, whether it happens before conception, such as abuse experienced by the mother as a child, or during adult life in the form of interpersonal violence $^{65,70-72}$. PNMS is documented to influence birth and the timing of delivery in addition to increasing the risk of adverse pregnancy outcomes ${ }^{39,73-75}$. Likewise, pre-conceptional stress in the father can epigenetically alter the sperm characteristics to increase the risk of NCDs in generations of offspring $^{76}$. Considerable data have convincingly demonstrated that natural disasters (e.g. ice storms that disrupt electrical power for weeks or floods) have a profound effect on PNMS, which in turn has considerably affected pregnancy outcomes and child development ${ }^{32,45,77-79}$.

Stress is inherent to life, pregnancy, and transmission to offspring. This pertains to fathers as well as mothers; the developmental timepoint and type of paternal stress influence the transfer of these phenotypes to offspring and subsequent generations $s^{80}$. Hence, a single stressor is hardly representative of day-to-day life for many pre-conception or pregnant women and their partners. Rather, the most at-risk populations and individuals experience a multiplicity of stressors which collectively add to an individual's overall stress load, or what is known as allostatic load. These repeated or chronic stresses lead to an increased allostatic load that represents the "wear and tear" of these stressors on the mind and body. When this becomes overwhelming, it can lead to an adverse health outcome $^{81,82}$. Clearly, the accumulated stressors due to climate change can lead to increased allostatic load.

Stress has also been shown to increase the susceptibility of an individual to infections and to be associated with a proinflammatory profile ${ }^{83-86}$. Recently, a "two-hit" model of psychological and inflammatory stress dramatically increased the variability of timing of gestation length in pregnant rats $^{87,88}$. It also demonstrated that maternal psychological stress induced anxiety in male and female offspring adults, whereas the inflammatory stress increased exploratory and risk-taking behavior only in adult female offspring. This is another way that climate change can affect fetal/newborn development in that it can alter the environment the fetus is programmed to expect upon birth, creating a metabolic mismatch that alters its newborn and/or adult health.

\section{Conclusion: addressing the effects of the climate crisis on maternal-child health}

Studies have been discussed that suggest that climate change stressors impact fathers as well as mothers, that climate change stressors accumulate, reaching a "tipping point" that can propel the individual away from health and towards adverse pregnancy outcomes and/or adverse offspring development, that climate change stress may be passed on to succeeding generations, and that climate change may lead to a mismatch between the type of environment the fetus was programmed to expect and the type of environment it actually encounters, thereby resulting in altered development and/or adult health.

The climate crisis is a health threat multiplier that amplifies the vulnerability of the most at-risk populations ${ }^{5,89}$. It accelerates the increase in allostatic load of the most at risk. The path of tragedy begins with an accumulating allostatic load that overwhelms resilience. This leads to worse mental health including depression and anxiety and, in the case of pregnant women, their partners, and their children, more adverse pregnancy outcomes and impaired developmental trajectories. As confirmation, study after study identifies pregnant women and young children as being one of the most at-risk groups affected by the climate crisis ${ }^{3,4,89}$.

Individuals are generally protected against these adverse health outcomes by one's personal and/or community resilience. Resilience is defined in both the individual and the socioecological context ${ }^{90}$, which is "the capacity of a socio-ecological system to cope with a hazardous event or disturbance, responding or reorganizing in ways that maintain its essential function, identity and structure, while also maintaining the capacity for adaptation, learning and transformation" ${ }^{\prime 1}$. But the adverse pregnancy and development problems occur when climate change stressors increase allostatic load to a level where one's resilience, or the resilience of a community, is overwhelmed.

An Australian conceptual framework ${ }^{92}$ argues that a binary approach is needed to address these climate change effects. At one level, there is a vital need to mitigate the very significant, global, and highly political issues of reducing greenhouse gas emissions, enhancing carbon sinks, switching from carbon fuels to renewable energy sources, reducing pollution, and switching to alternative food sources. At the same time, interventions that more directly address the stress and mental health problems that concern pre-conceptual women and men (high school and university students), pregnant and post-partum women, and their young children require attention. The World Health Organization recommends population-based interventions over those aimed at high-risk individuals, primary over secondary interventions, and controlling distal rather than proximal climate change risks to health ${ }^{93}$.

Finally, there is a need to create new tools that will predict individuals and communities at the greatest risk and new interventions to reduce these risks, reduce stress, and increase resilience. It is also possible to rediscover "old tools" that work well for some communities who learn how to apply them with the goal of enhancing both individual- and community-level resilience. An example of rediscovering old tools is highlighted by a recent study of Inuit youth aged 15-25 from the Canadian Arctic who are experiencing rapid changes in climate conditions. They identified five factors that are a throwback to more traditional ways used by their community to reduce depression and anxiety and improve mental health and wellbeing. They are 1) being on the land, 2) connecting to Inuit culture, 3) maintaining strong communities, 4) maintaining 
positive relationships with family and friends, and 5) staying busy $^{94}$. Learning from community studies like these will open new avenues for better intervention and resilience building for larger population-based strategies and policies that support health in mothers, their children, and future generations.

\section{Acknowledgements}

DMO and GASM are directors of the Optimal Pregnancy Environment Risk Assessment (OPERA) program sponsored by the Worldwide Universities Network.
1. IPCC: Global warming of $1.5^{\circ} \mathrm{C}$. An IPCC Special Report on the impacts of global warming of $1.5^{\circ} \mathrm{C}$ above pre-industrial levels and related global greenhouse gas emission pathways in the context of strengthening the global response to the threat of climate change. Geneva, Switzerland: World Meteorlogical Organization, 2018.

Reference Source

2. Bourque F, Willox AC: Climate change: the next challenge for public mental health? Int Rev Psychiatry. 2014; 26(4): 415-22.

PubMed Abstract | Publisher Full Text

3. Watts N, Amann M, Arnell N, et al.: The $\mathbf{2 0 1 8}$ report of the Lancet Countdown on health and climate change: shaping the health of nations for centuries to come. Lancet. 2018; 392(10163): 2479-514. PubMed Abstract | Publisher Full Text | Faculty Opinions Recommendation

4. Watts N, Amann M, Arnell N, et al.: The 2019 report of The Lancet Countdown on health and climate change: ensuring that the health of a child born today is not defined by a changing climate. Lancet. 2019; 394(10211): 1836-78.

PubMed Abstract | Publisher Full Text | Faculty Opinions Recommendation

5. Hayes K, Blashki G, Wiseman J, et al.: Climate change and mental health: risks, impacts and priority actions. Int J Ment Health Syst. 2018; 12: 28. PubMed Abstract | Publisher Full Text | Free Full Text | Faculty Opinions Recommendation

6. Middleton J, Cunsolo A, Jones-Bitton A, et al.: Indigenous mental health in a changing climate: A systematic scoping review of the global literature. Environ Res Lett. 2020; 15: 53001.

Publisher Full Text | Faculty Opinions Recommendation

7. Philipsborn RP, Chan K: Climate Change and Global Child Health. Pediatrics. 2018; 141(6): e20173774.

PubMed Abstract | Publisher Full Text | Faculty Opinions Recommendation

8. Buse CG, Lai V, Cornish K, et al.: Towards environmental health equity in health impact assessment: innovations and opportunities. Int J Public Health. 2019; 64(1): 15-26.

PubMed Abstract | Publisher Full Text | Faculty Opinions Recommendation

9. Parry L, Radel C, Adamo SB, et al.: The (in)visible health risks of climate change. Soc Sci Med. 2019; 241: 112448.

PubMed Abstract | Publisher Full Text | Faculty Opinions Recommendation

10. Barreca A, Schaller J: The impact of high ambient temperatures on delivery timing and gestational lengths. Nature Climate change. 2020; 10(1): 77-82. Publisher Full Text | Faculty Opinions Recommendation

11. Poursafa P, Keikha M, Kelishadi R: Systematic review on adverse birth outcomes of climate change. J Res Med Sci. 2015; 20(4): 397-402. PubMed Abstract | Free Full Text

12. Sheffield PE, Landrigan PJ: Global climate change and children's health: threats and strategies for prevention. Environ Health Perspect. 2011; 119(3): 291-8.

PubMed Abstract | Publisher Full Text | Free Full Text

13. Barker DJ: The fetal and infant origins of adult disease. BMJ. 1990; 301(6761): 1111

PubMed Abstract | Publisher Full Text | Free Full Text

14. Gluckman PD, Hanson MA, Buklijas T: A conceptual framework for the developmental origins of health and disease. J Dev Orig Health Dis. 2010; 1(1): 6-18.

PubMed Abstract | Publisher Full Text

15. Randell H, Gray C: Climate change and educational attainment in the global tropics. Proc Natl Acad Sci U S A. 2019; 116(18): 8840-5. PubMed Abstract | Publisher Full Text | Free Full Text | Faculty Opinions Recommendation

16. Burke SEL, Sanson AV, van Hoorn J: The Psychological Effects of Climate
Change on Children. Curr Psychiatry Rep. 2018; 20(5): 35.

PubMed Abstract | Publisher Full Text | Faculty Opinions Recommendation

17. World Health Organization: Global Health Observatory (GHO) data. NCD mortality and morbidity. 2020.

Reference Source

18. Becker $A E$, Kleinman $A$ : Mental health and the global agenda. $N$ EnglJ Med. 2013; 369(1): 66-73.

PubMed Abstract | Publisher Full Text

19. Berry HL, Bowen $\mathrm{K}$, Kjellstrom $\mathrm{T}$ : Climate change and mental health: a causal pathways framework. Int J Public Health. 2010; 55(2): 123-32.

PubMed Abstract | Publisher Full Text

20. Hayes K, Poland B: Addressing Mental Health in a Changing Climate: Incorporating Mental Health Indicators into Climate Change and Health Vulnerability and Adaptation Assessments. Int J Environ Res Public Health. 2018; 15(9): 1806

2018; 15(9): 1806.
PubMed Abstract | Publisher Full Text | Free Full Text | Faculty Opinions Recommendation

21. Hayes K, Berry P, Ebi KL: Factors Influencing the Mental Health Consequences of Climate Change in Canada. Int J Environ Res Public Health. 2019; 16(9): 1583.

PubMed Abstract | Publisher Full Text | Free Full Text | Faculty Opinions Recommendation

22. Ebi KL, Berry P, Hayes K, et al.: Stress Testing the Capacity of Health Systems to Manage Climate Change-Related Shocks and Stresses. Int Environ Res Public Health. 2018; 15(11): 2370.

PubMed Abstract | Publisher Full Text | Free Full Text |

Faculty Opinions Recommendation

23. Majeed $\mathrm{H}$, Lee J: The impact of climate change on youth depression and mental health. Lancet Planet Health. 2017; 1(3): e94-e95. PubMed Abstract | Publisher Full Text

24. Goenjian AK, Molina L, Steinberg AM, et al.: Posttraumatic stress and depressive reactions among Nicaraguan adolescents after hurricane Mitch. Am J Psychiatry. 2001; 158(5): 788-94. PubMed Abstract | Publisher Full Text

25. Norris FH, Friedman MJ, Watson PJ, et al: 60,000 disaster victims speak: Part I. An empirical review of the empirical literature, 1981-2001. Psychiatry. 2002; 65(3): 207-39.

PubMed Abstract | Publisher Full Text

26. Norris FH, Friedman MJ, Watson PJ: 60,000 disaster victims speak: Part II. Summary and implications of the disaster mental health research. Psychiatry. 2002; 65(3): 240-60.

PubMed Abstract | Publisher Full Text

27. Albrecht G: "Solastalgia." A New Concept in Health and Identity. PAN Philos Act Nat. 2005; 3: 41

Reference Source

28. Albrecht G: Solastalgia and the creation of new ways of living. In: Nature and Culture: Rebuilding Lost Connections. Pilgrim, S, Pretty, J, Eds. Earthscan: London, UK. 2010; 217-234.

Publisher Full Text

29. Albrecht G: Earth Emotions: New Words for a New World. Cornell University Press; Ithaca, NY, USA, 2019

Reference Source

30. Galway LP, Beery T, Jones-Casey K, et al.: Mapping the Solastalgia Literature: A Scoping Review Study. Int J Environ Res Public Health. 2019; 16(15): 2662.

PubMed Abstract | Publisher Full Text | Free Full Text | Faculty Opinions Recommendation

31. Cunsolo A, Ellis NR: Ecological grief as a mental health response to climate change-related loss. Nat Clim Change. 2018; 8: 275-81. Publisher Full Text | Faculty Opinions Recommendation

32. Charil A, Laplante DP, Vaillancourt C, et al.: Prenatal stress and brain 
development. Brain Res Rev. 2010; 65(1): 56-79. PubMed Abstract | Publisher Full Text

33. Weinstock $M$ : Alterations induced by gestational stress in brain morphology and behaviour of the offspring. Prog Neurobiol. 2001; 65(5): 427-51. PubMed Abstract | Publisher Full Text

34. Weinstock M: Sex-dependent changes induced by prenatal stress in cortical and hippocampal morphology and behaviour in rats: an update. Stress. 2011; 14(6): 604-13.

PubMed Abstract | Publisher Full Text

35. Weinstock M, Poltyrev T, Schorer-Apelbaum D, et al: Effect of prenatal stress on plasma corticosterone and catecholamines in response to footshock in rats. Physiol Behav. 1998; 64(4): 439-44.

PubMed Abstract | Publisher Full Text

36. Glover V: Annual Research Review: Prenatal stress and the origins of psychopathology: an evolutionary perspective.J Child Psychol Psychiatry. 2011: 52(4): 356-67.

PubMed Abstract | Publisher Full Text

37. Graignic-Philippe R, Dayan J, Chokron S, et al.: Effects of prenatal stress on fetal and child development: a critical literature review. Neurosci Biobehav Rev. 2014; 43: 137-62.

PubMed Abstract | Publisher Full Tex

38. Talge NM, Neal C, Glover V: Antenatal maternal stress and long-term effects on child neurodevelopment: how and why? J Child Psychol Psychiatr. 2007; 48(3-4): 245-61.

PubMed Abstract | Publisher Full Text | Faculty Opinions Recommendation

39. Christiaens I, Hegadoren K, Olson DM: Adverse childhood experiences are associated with spontaneous preterm birth: a case-control study. BMC Med. 2015; $13: 124$.

PubMed Abstract | Publisher Full Text | Free Full Text

40. Nesari M, Olson JK, Vandermeer B, et al.: Does a maternal history of abuse before pregnancy affect pregnancy outcomes? A systematic review with meta-analysis. BMC Pregnancy Childbirth. 2018; 18(1): 404

PubMed Abstract | Publisher Full Text | Free Full Text

41. Watt TT, Appel L, Roberts K, et al.: Sugar, stress, and the Supplemental Nutrition Assistance Program: early childhood obesity risks among a clinic-based sample of low-income Hispanics. J Community Health. 2013; 38(3): 513-20.

PubMed Abstract | Publisher Full Text

42. Virk J, Li J, Vestergaard M, et al.: Prenatal exposure to bereavement and type2 diabetes: a Danish longitudinal population based study. PLoS One. 2012 7(8): e43508.

PubMed Abstract | Publisher Full Text | Free Full Text

43. Entringer S, Wüst S, Kumsta R, et al.: Prenatal psychosocial stress exposure is associated with insulin resistance in young adults. Am J Obstet Gynecol. 2008; 199(5): 498.e1-7.

PubMed Abstract | Publisher Full Text | Free Full Text

Faculty Opinions Recommendation

44. Flory JD, Bierer LM, Yehuda R: Maternal exposure to the holocaust and health complaints in offspring. Dis Markers. 2011: 30(2-3): 133-9. PubMed Abstract | Publisher Full Text | Free Full Text

45. King S, Laplante DP: The effects of prenatal maternal stress on children's cognitive development: Project Ice Storm. Stress. 2005; 8(1): 35-45. PubMed Abstract | Publisher Full Text

46. O'Connor TG, Winter MA, Hunn J, et al.: Prenatal maternal anxiety predicts reduced adaptive immunity in infants. Brain Behav Immun. 2013; 32: 21-8. PubMed Abstract | Publisher Full Text | Free Full Text

47. Cyr K, Chamberland C, Clément M-È, et al.: The Impact of Lifetime Victimization and Polyvictimization on Adolescents in Québec: Mental Health Symptoms and Gender Differences. Violence Vict. 2017; 32(1): 3-21. PubMed Abstract | Publisher Full Text

48. Isganaitis $\mathrm{E}$, Suehiro $\mathrm{H}, \mathrm{Cardona} \mathrm{C}$ : Who's your daddy?: paternal inheritance of metabolic disease risk. Curr Opin Endocrinol Diabetes Obes. 2017; 24(1): 47-55.

PubMed Abstract | Publisher Full Text

49. $\mathrm{Ng} \mathrm{C}$, Corey PN, Young TK: Socio-economic patterns of obesity among aboriginal and non-Aboriginal Canadians. Can J Public Health. 2011; 102(4): 264-8.

PubMed Abstract | Publisher Full Text | Free Full Text

50. Sweeting HN: Gendered dimensions of obesity in childhood and adolescence. Nutr J. 2008; 7: 1

PubMed Abstract | Publisher Full Text | Free Full Text

51. Rich-Edwards JW, Grizzard TA: Psychosocial stress and neuroendocrin mechanisms in preterm delivery. Am J Obstet Gynecol. 2005; 192(5 Suppl): \$30-5.

PubMed Abstract | Publisher Full Text

52. Porter $\mathrm{T}$, Fraser $\mathrm{A}$, Hunter $\mathrm{C}$, et al:: The risk of preterm birth acros generations. Obstet Gynecol. 1997: 90(1): 63-7. PubMed Abstract | Publisher Full Text

53. Coussons-Read ME, Lobel M, Carey JC, et al.: The occurrence of preterm delivery is linked to pregnancy-specific distress and elevated inflammatory markers across gestation. Brain Behav Immun. 2012; 26(4): $650-9$

PubMed Abstract | Publisher Full Text | Free Full Text
54. Crews D, Gillette R, Scarpino SV, et al.: Epigenetic transgenerational inheritance of altered stress responses. Proc Natl Acad Sci U S A. 2012; 109(23): 9143-8.

PubMed Abstract | Publisher Full Text | Free Full Text |

Faculty Opinions Recommendation

55. Zucchi FCR, Yao Y, Ward ID, et al.: Maternal stress induces epigenetic signatures of psychiatric and neurological diseases in the offspring. PLOS One. 2013; 8(2): e56967.

PubMed Abstract | Publisher Full Text | Free Full Text

56. Kaati G, Bygren LO, Edvinsson S: Cardiovascular and diabetes mortality determined by nutrition during parents' and grandparents' slow growth period. Eur J Hum Genet. 2002; 10(11): 682-8.

PubMed Abstract | Publisher Full Text | Faculty Opinions Recommendation

57. Franklin TB, Linder $\mathrm{N}$, Russig $\mathrm{H}$, et al.: Influence of early stress on social abilities and serotonergic functions across generations in mice. PLOS One. 2011; 6(7): e21842.

PubMed Abstract | Publisher Full Text | Free Full Text

58. Weiss IC, Franklin TB, Vizi S, et al.: Inheritable effect of unpredictable maternal separation on behavioral responses in mice. Front Behav Neurosci. 2011; 5: 3.

PubMed Abstract | Publisher Full Text | Free Full Text

59. Ward ID, Zucchi FCR, Robbins JC, et al.: Transgenerational programming of maternal behaviour by prenatal stress. BMC Pregnancy Childbirth. 2013; 13 Suppl 1(Suppl 1): S9.

PubMed Abstract | Publisher Full Text | Free Full Text

60. Yao Y, Robinson AM, Zucchi FCR, et al.: Ancestral exposure to stress epigenetically programs preterm birth risk and adverse maternal and newborn outcomes. BMC Med. 2014; 12: 121.

PubMed Abstract | Publisher Full Text | Free Full Text

61. Jiang $H Y, X u L L$, Shao $L$, et al.: Maternal infection during pregnancy and risk of autism spectrum disorders: A systematic review and meta-analysis. Brain Behav Immun. 2016; 58: 165-72.

PubMed Abstract | Publisher Full Text

62. Murphy SK, Fineberg AM, Maxwell SD, et al.: Maternal infection and stress during pregnancy and depressive symptoms in adolescent offspring. Psychiatry Res. 2017; 257: 102-10.

PubMed Abstract | Publisher Full Text | Free Full Text

63. Say GN, Karabekiroğlu K, Babadağı Z, et al.: Maternal stress and perinata features in autism and attention deficit/hyperactivity disorder. Pediatr Int 2016; 58(4): 265-9.

PubMed Abstract | Publisher Full Text

64. Aiken CE, Ozanne SE: Transgenerational developmental programming. Hum Reprod Update. 2014; 20(1): 63-75.

PubMed Abstract | Publisher Full Text | Faculty Opinions Recommendation

65. Toepfer P, Heim C, Entringer S, et al.: Oxytocin pathways in the intergenerational transmission of maternal early life stress. Neurosci Biobehav Rev. 2017; 73: 293-308.

PubMed Abstract | Publisher Full Text | Free Full Text

66. Kane JB, Harris KM, Siega-Riz AM: Intergenerational pathways linking maternal early life adversity to offspring birthweight. Soc Sci Med. 2018; 207: 89-96.

PubMed Abstract | Publisher Full Text | Free Full Text Faculty Opinions Recommendation

67. Franklin TB, Russig H, Weiss IC, et al.: Epigenetic transmission of the impact of early stress across generations. Biol Psychiatry. 2010; 68(5): 408-15. PubMed Abstract | Publisher Full Text | Faculty Opinions Recommendation

68. Casavant SG, Cong X, Fitch RH, et al.: Allostatic Load and Biomarkers of Stress in the Preterm Infant: An Integrative Review. Biol Res Nurs. 2019; 21(2): 210-223.

PubMed Abstract | Publisher Full Text | Faculty Opinions Recommendation

69. Yehuda R, Lehrner A: Intergenerational transmission of trauma effects: Putative role of epigenetic mechanisms. World Psychiatry. 2018; 17(3): 243-

PubMed Abstract | Publisher Full Text | Free Full Text | Faculty Opinions Recommendation

70. Palma-Gudiel H, Córdova-Palomera A, Eixarch E, et al:: Maternal psychosocial stress during pregnancy alters the epigenetic signature of the glucocorticoid receptor gene promoter in their offspring: A meta-analysis. Epigenetics. 2015; 10(10): 893-902. PubMed Abstract | Publisher Full Text | Free Full Text

71. Yehuda R, Daskalakis NP, Bierer LM, et al.: Holocaust Exposure Induced Intergenerational Effects on FKBP5 Methylation. Biol Psychiatry. 2016; 80(5): 372-80.

PubMed Abstract | Publisher Full Text | Faculty Opinions Recommendation

72. McGowan PO, Suderman M, Sasaki A, et al: Broad epigenetic signature of maternal care in the brain of adult rats. PLOS One. 2011; 6(2): e14739. PubMed Abstract | Publisher Full Text | Free Full Text

73. Bublitz MH, Bourjeily G, Vergara-Lopez C, et al.: Momentary stress, cortisol, and gestational length among pregnant victims of childhood maltreatment: A pilot study. Obstet Med. 2016; 9(2): 73-7. PubMed Abstract | Publisher Full Text | Free Full Text 
74. Lilliecreutz C, Larén J, Sydsjö G, et al.: Effect of maternal stress during pregnancy on the risk for preterm birth. BMC Pregnancy Childbirth. 2016; 16: 5. PubMed Abstract | Publisher Full Text | Free Full Text

75. Margerison-Zilko CE, Strutz KL, Li Y, et al.: Stressors Across the Life-Course and Preterm Delivery: Evidence From a Pregnancy Cohort. Matern Child Health J. 2017; 21(3): 648-58.

PubMed Abstract | Publisher Full Text | Free Full Text

76. Soubry A: POHaD: Why we should study future fathers. Environ Epigenet 2018; 4(2): dvy007.

PubMed Abstract | Publisher Full Text | Free Full Text Faculty Opinions Recommendation

77. King S, Dancause K, Turcotte-Tremblay AM, et al.: Using natural disasters to study the effects of prenatal maternal stress on child health and development. Birth Defects Res C Embryo Today. 2012; 96(4): 273-88. PubMed Abstract | Publisher Full Text

78. Dancause KN, Laplante DP, Hart KJ, et al.: Prenatal stress due to a natural disaster predicts adiposity in childhood: The Iowa Flood Study. J Obes. 2015; 2015: 570541.

PubMed Abstract | Publisher Full Text | Free Full Text

79. Liu GT, Dancause KN, Elgbeili G, et al.: Disaster-related prenatal maternal stress explains increasing amounts of variance in body composition through childhood and adolescence: Project Ice Storm. Environ Res. 2016; 150: $1-7$.

PubMed Abstract | Publisher Full Text

80. Cunningham AM, Walker DM, Nestler EJ: Paternal transgenerational epigenetic mechanisms mediating stress phenotypes of offspring. Eur J Neurosci. 2019.

PubMed Abstract | Publisher Full Text | Free Full Text |

Faculty Opinions Recommendation

81. Sterling $\mathrm{P}$, Eyer J: Allostasis: a new paradigm to explain arousal pathol- ogy. In: Fisher S, JR (ed.), Handbook of Life Stress, Cognition and Health. New York: John Wiley \& Sons; 1988 Reference Source

82. McEwen BS: Stress, adaptation, and disease. Allostasis and allostatic load. Ann N Y Acad Sci. 1998; 840: 33-44.

PubMed Abstract | Publisher Full Text

83. Schiltz JC, Sawchenko PE: Signaling the brain in systemic inflammation: The role of perivascular cells. Front Biosci. 2003; 8: s1321-9.

PubMed Abstract | Publisher Full Text

84. Coussons-Read ME, Okun ML, Schmitt MP, et al.: Prenatal stress alters cytokine levels in a manner that may endanger human pregnancy. Psychosom Med. 2005; 67(4): 625-31.

PubMed Abstract | Publisher Full Text

85. Glaser R, Kiecolt-Glaser JK: Stress-induced immune dysfunction: Implications for health. Nat Rev Immunol. 2005; 5(3): 243-51.

PubMed Abstract | Publisher Full Text

86. Hueston CM, Deak T: The inflamed axis: The interaction between stress, hormones, and the expression of inflammatory-related genes within key structures comprising the hypothalamic-pituitary-adrenal axis. Physiol Behav. 2014; 124: 77-91.

PubMed Abstract | Publisher Full Text

87. Verstraeten BSE, McCreary JK, Weyers S, et al.: Prenatal two-hit stress affects maternal and offspring pregnancy outcomes and uterine gene expression in rats: Match or mismatch? Biol Reprod. 2019; 100(1): 195-207. PubMed Abstract | Publisher Full Text | Free Full Text

88. Verstraeten BSE, McCreary JK, Falkenberg EA, et al.: Multiple prenatal stresses increase sexual dimorphism in adult offspring behavior. Psychoneuroendocrinology. 2019; 107: 251-60. PubMed Abstract | Publisher Full Text

89. McMichael AJ: Climate change and the health of nations: famines, fevers, and the fate of populations. Oxford, Oxford University Press. 2017. Reference Source

90. Brémault-Phillips S, Pike A, Olson J, et al.: Expressive writing for wildfireaffected pregnant women: Themes of challenge and resilience. International Journal of Disaster Risk Reduction. 2020; 50: 101730. Publisher Full Text

91. WHO Report: Strengthening resilience: a priority shared by Health 2020 and the Sustainable Development Goals. 2017. Reference Source

92. Boylan S, Beyer K, Schlosberg D, et al:: A conceptual framework for climate change, health and wellbeing in NSW, Australia. Public Health Res Pract. 2018; 28(4): 2841826.

PubMed Abstract | Publisher Full Text | Faculty Opinions Recommendation

93. World Health Organization: The World Health Report 2013. Chapter 6 Choosing priority strategies for risk prevention. 2020. Reference Source

94. MacDonald JP, Ford JD, Willox AC, et al.: A review of protective factors and causal mechanisms that enhance the mental health of Indigenous Circumpolar youth. Int J Circumpolar Health. 2013; 72: 21775. PubMed Abstract | Publisher Full Text | Free Full Text 


\section{Open Peer Review}

\section{Current Peer Review Status:}

\section{Editorial Note on the Review Process}

Faculty Reviews are review articles written by the prestigious Members of Faculty Opinions. The articles are commissioned and peer reviewed before publication to ensure that the final, published version is comprehensive and accessible. The reviewers who approved the final version are listed with their names and affiliations.

\section{The reviewers who approved this article are:}

\section{Version 1}

\section{Kevin Chan}

Department of Pediatrics, University of Toronto, Toronto, Canada

Competing Interests: No competing interests were disclosed.

\section{Lindsay Galway}

Department of Health Sciences, Lakehead University, Thunder Bay, ON, Canada

Competing Interests: No competing interests were disclosed.

\section{Katie Hayes}

Policy Analyst, Climate Change and Innovation Bureau, Health, Toronto, Canada

Competing Interests: No competing interests were disclosed.

The benefits of publishing with F1000Research:

- Your article is published within days, with no editorial bias

- You can publish traditional articles, null/negative results, case reports, data notes and more

- The peer review process is transparent and collaborative

- Your article is indexed in PubMed after passing peer review

- Dedicated customer support at every stage

For pre-submission enquiries, contact research@f1000.com 